\title{
Probabilistic geotechnical designs in rural road infrastructure in Costa Rica
}

\author{
Rafael Baltodano-Goulding ${ }^{1,2}$ \\ ${ }^{1}$ LabUnsat, Civil Engineering Department, University of Costa Rica, Costa Rica \\ ${ }^{2}$ Construction Engineering, Costa Rica Institute of Technology, Costa Rica
}

\begin{abstract}
Rural road infrastructure normally lacks information to perform rigorous geotechnical designs, due especially, to budgeting restrictions. Three different transportation projects in rural areas in Costa Rica are presented, where a probabilistic approach was followed. The statistical parameters selected from previous research can be used as local literature values to perform probabilistic geotechnical designs and analyses when there is not enough data to execute a statistical analysis in a project. Moreover, these values could be used to better understand values obtained from geotechnical site exploration and possible regional tendencies. It is possible to conduct probabilistic geotechnical design even when a project does not include a throughout site exploration, like in low-budget projects. Probabilistic design for rural road projects can be a useful tool in the pursuit of optimal and efficient designs where soil behavior is better understood.
\end{abstract}

\section{Introduction}

Rural road infrastructure normally lacks enough information to perform rigorous geotechnical designs due especially to budgeting restrictions. Thus, it is common practice to perform deterministic geotechnical designs that focus on obtaining a factor of safety for the different scenarios considered. The problem of not being able to accurately quantify the uncertainty of the structure could lead to costly overdesigns, or even worse, to an inaccurate assessment of the safety levels.

It is well-known that a probabilistic-based design could greatly reduce the uncertainty associated with spatial, soil properties, and environmental variables. Spatial uncertainty is related to the soil strata, topography, geological origin, and groundwater levels. Data uncertainty is related to a lack of understanding of the soil's behavior and geotechnical properties. And, environmental uncertainty is related to climate variables, seismic activity, and surcharges. Therefore, a probabilistic-based design allows the designer to better understand all variables involved in the project's analysis and optimized it. However, in many projects, there is not enough information available to obtain the statistical parameter necessary to perform a probabilistic design.

To perform a probabilistic geotechnical design, it is necessary to have average values and corresponding standard deviations for the variables that the designer considers important for the analysis. These values could be obtained in three different ways: having enough data to perform statistical analysis, using values presented in technical literature, such as the values recommended by
The United States Army Corps of Engineers, and running simulations, such as Monte Carlo. In addition to its applicability for design, having such statistical information can provide a general idea of soil's behavior and data trends. Also, this information is useful to compare and verify results obtained from the geotechnical exploration.

Three different transportation projects in rural areas in Costa Rica are presented, where a probabilistic approach was followed. The statistical parameter used for the analysis were obtained from a previous research project directed by the author where a map showing different regions of similar geotechnical values was developed for Costa Rica. The geotechnical parameters considered in the map are the effective angle of friction of the soil, unit weights, undrained cohesion, and degree of saturation. The initial objective of the map was to quantify the effect of changes in the degree of saturation in the shear strength parameters of the soil, to reduce the uncertainty of this data. It is worth mentioning that good agreement was observed with maps for climate conditions and soil orogenesis for the same regions.

\section{Methodology}

Probabilistic-based designs were performed to demonstrate the usefulness of the statistical parameters derived for Costa Rica. These values are especially useful when there is not enough information to complete a statistical analysis and literature information must be used. The projects presented are a bridge deep foundation design, a Mechanically Stabilized Earth Wall (MSEW),

\footnotetext{
* Corresponding author: rafael.baltodanogoulding@ucr.ac.cr
} 
and a project where two alternatives were considered: an MSEW, and a gabion wall. The design presented is based on the global stability of the slope, internal and external stability, although analyzed, are not presented.

The slope stability analyses were done using the software Slide ${ }^{\circledR}$ from Rocscience Inc. The Monte Carlo capabilities of this software were used introducing to the model the standard deviation and average of the different soil's characteristics and resistance parameters. The total unit weight, undrained cohesion, and effective angle of friction of the soil values were selected from the geotechnical parameters maps previously developed. The mean safety factor, probability of failure, and reliability indexes were estimated for each case.

\subsection{Project 1}

This project consists of a bridge design supported by a group pile foundation over alluvial materials. Since project 1 presented alluvial soils drained shear strength parameters were used for the design. The geotechnical parameters used for this project are shown in (Table ).

The length of the bridge is 30 meters, the maximum level of the river is 313.1 meter AMSL, and the bridge foundation is supported by six piles with a diameter of 40 centimeters and 1.35-meter spacing.

It is important to mention that the values shown in table 1 are a combination of soil laboratory and field testing, the use of correlations, and engineering judgment. For project 1 diamond bit drilling was performed. [1].

Table 1. Soil Stratification for Project 1

\begin{tabular}{c|c|c|c}
\hline Depth $(\mathbf{m})$ & $\begin{array}{c}\text { Soil } \\
\text { Type }\end{array}$ & $\begin{array}{c}\text { Unit } \\
\text { weight } \\
\left(\text { ton } / \mathbf{m}^{\mathbf{3}}\right)\end{array}$ & $\begin{array}{c}\text { Friction } \\
\left.\text { angle } \mathbf{(}^{\circ}\right)\end{array}$ \\
\hline $0.00-9.50$ & $\begin{array}{c}\text { Sandy } \\
\text { soil }\end{array}$ & 1.70 & 32 \\
\hline
\end{tabular}

\subsection{Project 2 and 3}

Projects 2 and 3 involved landslides that affected the road's operation and were necessary to recuperate the subgrade and pavement structure. The instability of these last two projects is related to improper stormwater management and inadequate hydraulic structures. Consequently, in addition to designing an MSE wall using geogrids, proper hydraulic structures were also recommended. It is important to mention that for the third project a gabion wall was designed so the client could choose between the two options. (iError! No se encuentra el origen de la referencia.2).

Table 2. Probabilistic Geotechnical Designs presented.

\begin{tabular}{c|c|c}
\hline Project & $\mathbf{2}$ & $\mathbf{3}$ \\
\hline Description & Slope stability & Slope stability \\
\hline Geotech design & $\begin{array}{c}\text { MSE Wall using } \\
\text { geogrids }\end{array}$ & $\begin{array}{c}\text { MSE Wall using } \\
\text { geogrids } \\
\text { And Gabion Wall }\end{array}$ \\
\hline
\end{tabular}

Project 2 is a 7-meter-high, 64-meter-long wall with geogrids every 1 meter vertically. Project $3 \mathrm{a}$ is a 4.3meter-high, 64-meter-long wall with geogrids every 1 meter vertically, and Project $3 \mathrm{~b}$ is a 4.3 -meter-high, 64meter-long gabion wall with a 1-meter depth of footing.

The geotechnical parameters used for these projects are shown in (Table ). For projects 2 and 3 SPT testing and percussion dilled boreholes were done. [1].

\subsection{Determination of the probabilistic values}

The probabilistic analyses were performed with the values of the standard deviation and average of the total unit weight, undrained cohesion, and effective angle of friction for the geotechnical zoning established in Costa Rica [2] in previous research. With this information, it was possible to carry out the probabilistic design of the geotechnical structures that require the three projects considered. A map of Costa Rica showing the geotechnical zoning (Fig. 1) and the zones with data of the probabilistic parameters of undrained cohesion and total unit weight (Fig. 2) are shown. The black circle in both maps indicates the approximate location of all the projects. It can be observed that in the place of interest there are data of undrained cohesion and total unit weight. Also, it can be appreciated that two types of zones can be found in the projects, according to the geotechnical zoning: V3 and Am. The zone V3 consists of residual soil of volcanic origin with a high void ratio, high humidity, low unit weight, collapsible and soft. On the other hand, zone Am is defined as soft yellowish residual soil with high humidity content and good permeability [3].

Table 3. Soil Stratification for Projects 2 and 3

\begin{tabular}{|c|c|c|c|}
\hline Depth (m) & $\begin{array}{l}\text { Soil } \\
\text { Type }\end{array}$ & $\begin{array}{c}\text { Unit } \\
\text { weight } \\
\left(\text { ton } / \mathbf{m}^{3}\right)\end{array}$ & $\begin{array}{c}\text { Friction } \\
\text { angle }\left({ }^{\circ}\right)\end{array}$ \\
\hline $0.00-3.60$ & $\begin{array}{l}\mathrm{MH} / \mathrm{CH} \\
\text { (USCS) }\end{array}$ & 1.80 & 17 \\
\hline $3.60-4.20$ & $\begin{array}{c}\mathrm{CH} \\
\text { (USCS) }\end{array}$ & 1.75 & 16 \\
\hline $4.20-6.60$ & $\begin{array}{l}\mathrm{MH} / \mathrm{CH} \\
\text { (USCS) }\end{array}$ & 1.75 & 16 \\
\hline $6.60-9.00$ & $\mathrm{CH}$ & 1.80 & 17 \\
\hline $9.00-12.00$ & (USCS) & 1.90 & 19 \\
\hline $12.00-15.60$ & $\begin{array}{l}\mathrm{CL} / \mathrm{CH} \\
\text { (USCS) }\end{array}$ & 1.85 & 18 \\
\hline $0.00-0.45$ & $\begin{array}{c}\text { Organic } \\
\text { soil }\end{array}$ & 2.00 & 20 \\
\hline $0.45-0.90$ & $\begin{array}{c}\mathrm{CL} \\
\text { (USCS) }\end{array}$ & & 25 \\
\hline $0.90-1.35$ & $\begin{array}{c}\text { - fine } \\
\text { clay } \\
\text { with } \\
\text { sand }\end{array}$ & 1.70 & 26 \\
\hline $1.35-2.25$ & $\begin{array}{c}\mathrm{CL} \\
\text { (USCS) }\end{array}$ & 1.95 & 32 \\
\hline
\end{tabular}




\begin{tabular}{c|c|c|c}
\hline Depth (m) & $\begin{array}{c}\text { Soil } \\
\text { Type }\end{array}$ & $\begin{array}{c}\text { Unit } \\
\text { weight } \\
\left(\text { ton } / \mathbf{m}^{3}\right)\end{array}$ & $\begin{array}{c}\text { Friction } \\
\left.\text { angle } \mathbf{(}^{\circ}\right)\end{array}$ \\
\hline & $\begin{array}{c}- \text { fine } \\
\text { clay } \\
\text { MH } \\
\text { (USCS) } \\
\text { elastic } \\
\text { silt }\end{array}$ & 1.96 & 30 \\
\hline
\end{tabular}

Considering the geotechnical zoning soil classification and the projects' locations, values of standard deviation, and the average for undrained cohesion and total unit weight were selected (Table 4). To pick proper values USCS soil classification system is used since for a particular zone many types of soil could be selected.

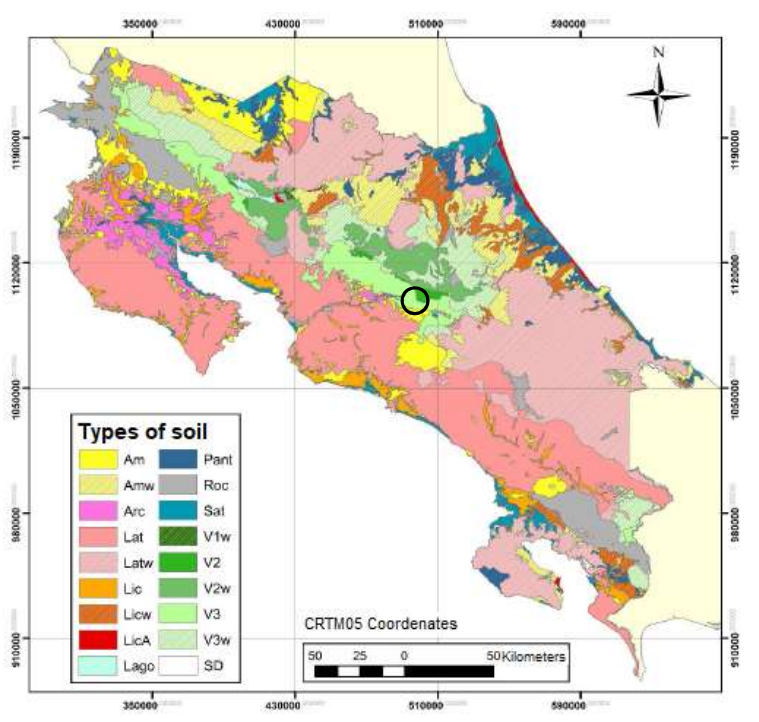

Fig. 1. Costa Rica's Geotechnical Zoning Map.

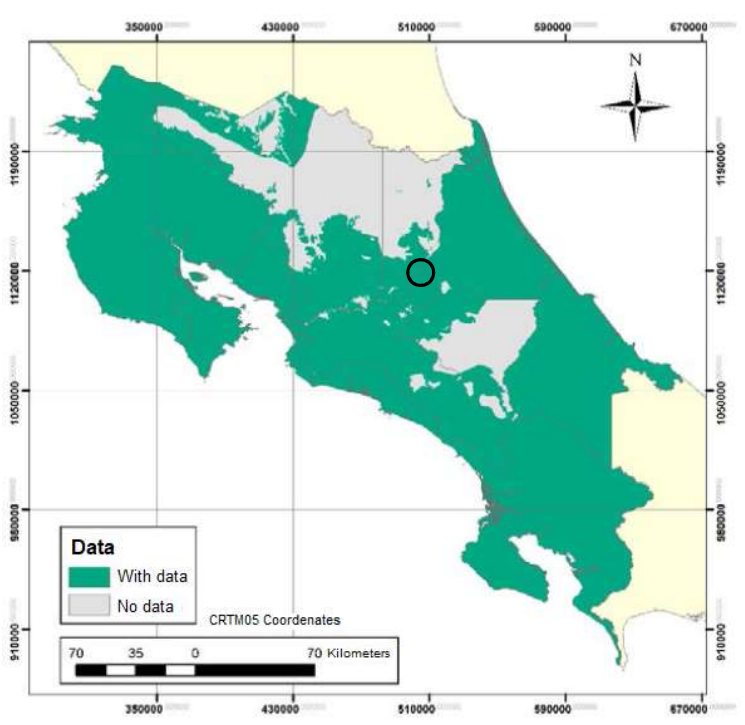

Fig. 2. Costa Rica's Areas with Statistical Data from previous research.
Table 4. Standard Deviation and Average Data for Undrained Cohesion and Total Unit Weight for the provinces of San Jose and Cartago, Costa Rica. [2,5]

\begin{tabular}{|c|c|c|c|c|c|}
\hline \multirow[t]{2}{*}{ Zone } & \multirow{2}{*}{$\begin{array}{c}\text { Soil } \\
\text { type } \\
\text { (USCS) }\end{array}$} & \multicolumn{2}{|c|}{$\begin{array}{l}\text { Cohesion } \\
\left(\text { ton } / \mathrm{m}^{2}\right)\end{array}$} & \multicolumn{2}{|c|}{$\begin{array}{c}\text { Total unit } \\
\text { weight } \\
\text { (ton } / \mathbf{m}^{3} \text { ) }\end{array}$} \\
\hline & & $\bar{x}$ & $S_{x}$ & $\overline{\bar{x}}$ & $S_{x}$ \\
\hline \multirow{4}{*}{ V3 } & $\mathrm{CL}$ & 10.42 & 6.76 & 1.82 & 0.05 \\
\hline & $\mathrm{CH}$ & 9.57 & 6.02 & 1.77 & 0.05 \\
\hline & ML & 8.35 & 5.93 & 1.77 & 0.05 \\
\hline & $\mathrm{MH}$ & 8.48 & 5.77 & 1.71 & 0.08 \\
\hline \multirow{3}{*}{$\mathrm{Am}$} & $\mathrm{CL}$ & 7.89 & 4.88 & 1.78 & 0.08 \\
\hline & $\mathrm{CH}$ & 10.14 & 6.46 & 1.78 & 0.07 \\
\hline & $\mathrm{ML}+\mathrm{MH}$ & 8.66 & 5.89 & 1.76 & 0.06 \\
\hline
\end{tabular}

Because the critical design condition for projects 2 and 3 is the undrained shear strength, only the statistical parameters associated with the total unit weight and undrained cohesion were used for the probabilistic design. For project 1, the standard deviation used was determined by comparing the total unit weight considered with the average from the V3 zone. For the other projects, the USCS soil classification was used to decide the standard deviations' values. In this case, V3 zone data was used for project 2 and Am zone data for project 3. It is worth mentioning that although the probabilistic analysis was done only for the critical scenario, the other scenarios were also check using a deterministic approach.

\subsection{Project Modeling for Probabilistic Design}

The program Slide ${ }^{\circledR}$ was used for the probabilistic design of these three rural road projects. The first thing that needs to be done in the program is to draw the structure with the terrain profile and the soil stratification. For project 1, there's only one soil stratum (Fig. 3) while project 2 (Fig. 4) and 3 (Fig. 5, Fig. 6) have various soil strata.

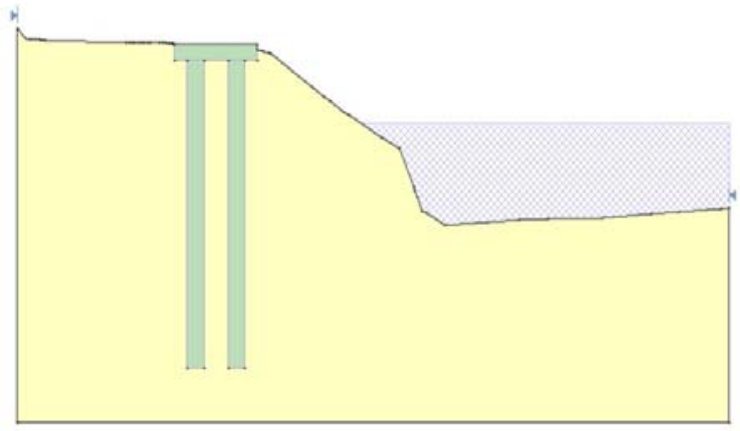

Fig. 3. Model of Project 1 for the Probabilistic Design. 


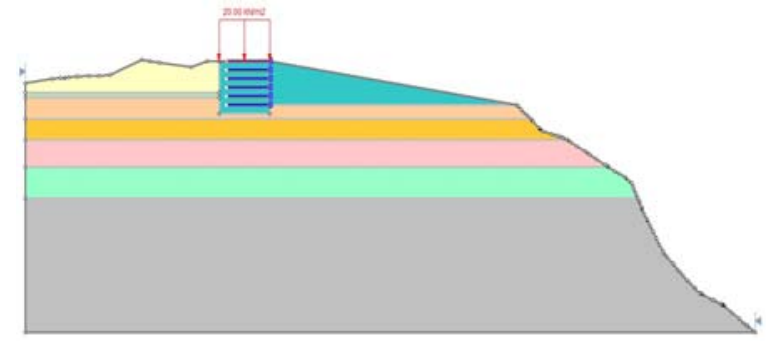

Fig. 4. Model of Project 2 for the Probabilistic Design.

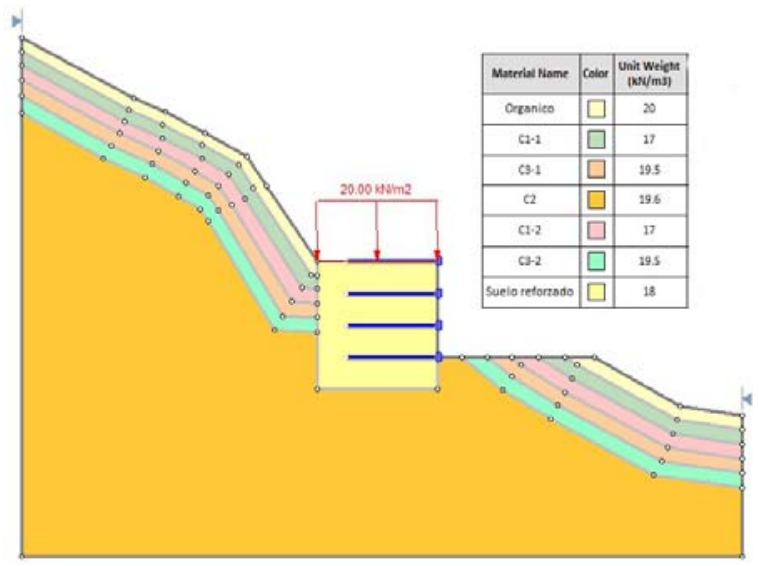

Fig. 5. Model A of Project 3 for the Probabilistic Design.

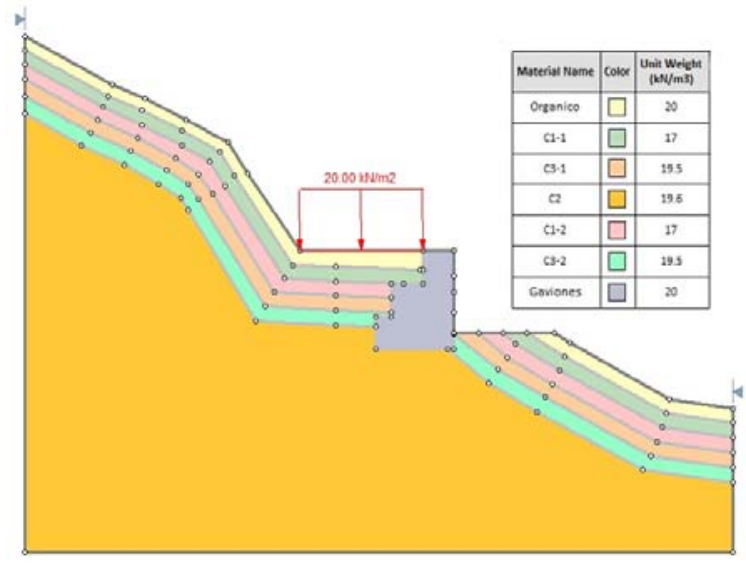

Fig. 6. Model B of Project 3 for the Probabilistic Design.

For project 1 to model all the forces transmitted to the piles, the modified total unit weight of the piles' concrete and the width side of the foundation was used in the model to account for the actual loading of the soil. Also, the water level was obtained from the water balance performed for this project. On the other hand, for the MSE walls, the geogrid's characteristics considered were of a passive force application (Method B) with an orientation parallel to the reinforcement, an anchorage in the slope face, $5 \mathrm{kPa}$ of adhesion, and a friction angle of $34^{\circ}$ for the pullout strength, $50 \%$ of strip coverage and strip tensile strength of $40 \mathrm{kN} / \mathrm{m}$. For the gabion's characteristics in project 3 , a $20 \mathrm{kN} / \mathrm{m}^{3}$ unit weight, $5 \mathrm{kN} / \mathrm{m}^{2}$ cohesion, and $35^{\circ}$ friction angle were considered in the model. It is important to mention that in models of projects 2 and 3, a surcharge load of $20 \mathrm{kN} / \mathrm{m}^{2}$ was used above the retaining walls to represent the traffic load.

The soil parameters introduced in each model for each soil stratum are shown in (Table 4). As stated before, because of the material's classification found in the river banks of project 1 and the material used for the retaining walls, the design condition for these projects is with undrained parameters. In the end, a maximum value of cohesion of $20 \mathrm{kPa}$ was accepted for the soils' strata with geotechnical criteria to avoid cases in which there is a failure surface that does not contemplate the soil-structure interaction as a whole.

Table 5. Soil parameters considered for all three projects' models for the probabilistic design.

\begin{tabular}{c|c|c|c|c|c}
\hline Prj & Depth (m) & $\begin{array}{c}\gamma_{T} \\
(\mathbf{k N} / \\
\left.\mathbf{m}^{3}\right)\end{array}$ & $\begin{array}{c}\boldsymbol{\varphi} \\
\left.\mathbf{(}^{\circ}\right)\end{array}$ & $\begin{array}{c}\boldsymbol{C}_{\mathbf{u}} \\
(\mathbf{k P a})\end{array}$ & $\begin{array}{c}\boldsymbol{\gamma}_{T} \boldsymbol{S}_{\boldsymbol{x}} \\
\left(\mathbf{k N} / \mathbf{m}^{3}\right)\end{array}$ \\
\hline 1 & $0.00-9.50$ & 17.0 & 32 & 5.3 & $0.8^{*}$ \\
\hline & $0.00-3.60$ & 18.0 & 17 & & 0.8 \\
& $3.60-4.20$ & 17.5 & 16 & & 0.5 \\
2 & $4.20-6.60$ & 17.5 & 16 & 20 & 0.8 \\
& $6.60-9.00$ & 18.0 & 17 & & 0.5 \\
& $9.00-12.00$ & 19.0 & 19 & & 0.5 \\
& $12.00-15.60$ & 18.5 & 18 & & 0.5 \\
\hline \multirow{3}{*}{3} & $0.00-0.45$ & 20.0 & 20 & & - \\
& $0.45-0.90$ & & 25 & & 0.8 \\
& $0.90-1.35$ & 17.0 & 26 & 10 & 0.8 \\
& $1.35-2.25$ & 19.5 & 32 & & 0.6 \\
& $2.25-2.70$ & 19.6 & 30 & & 0.8 \\
\hline
\end{tabular}

\section{Results}

The slope stability methods used to determine the global levels of safety for the structures were Bishop simplified, Janbu corrected, and Morgenstern \& Price. The mean and deterministic safety factor, the probability of failure, and the reliability index considering a normal and log-normal statistical distribution were estimated (Table).

The deterministic safety factor is the minimum of the model obtained from the regular slope stability analysis, and the mean safety factor is the average of all the safety factors calculated for the global minimum slip surface. The probability of failure is calculated as the ratio of the number of results with a safety factor less than one to the total number of runs. Finally, the reliability index is defined as the number of standard deviations that separate the mean safety factor from the critical one (when it equals one), and it can be calculated with a normal and log-normal statistical distribution.

\section{Discussion}

Costa Rica's Slope Stability Code (Código Geotecnico de Taludes y Laderas de Costa Rica, in Spanish) establishes a minimum safety factor for slope stability of 1.5 for a static force analysis [6]. Thus, in all projects, this factor of safety was fulfilled for both mean and deterministic 
safety factors. Project 1 exhibited the lowest safety factors for the three slope stability analyses performed, while project 3 with the gabion's wall alternative has the highest. Comparing the safety factors between the slope stability methods, for most of the projects considered, the highest safety factors were presented with the Janbu corrected method, except for project 1.

Concerning the probability of failure, because all the values of the safety factors of the projects are above the critical condition (equals to one), it is estimated that there is a probability of the global stability of the structure to fail near zero.

Table 6. Results from the projects' probabilistic design.

\begin{tabular}{|c|c|c|c|c|c|c|}
\hline \multicolumn{3}{|c|}{ Project } & 1 & 2 & 3. $\mathrm{a}^{1}$ & 3. $\mathbf{b}^{2}$ \\
\hline \multirow{15}{*}{ 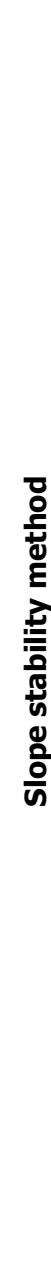 } & \multirow{5}{*}{ 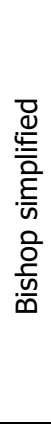 } & $\begin{array}{c}\text { Factor of } \\
\text { safety }\end{array}$ & 1.530 & 1.615 & 1.565 & 1.636 \\
\hline & & Mean FS & 1.530 & 1.614 & 1.565 & 1.635 \\
\hline & & $\begin{array}{l}\text { Prob. of } \\
\text { failure }\end{array}$ & $0 \%$ & $0 \%$ & $0 \%$ & $0 \%$ \\
\hline & & $\begin{array}{c}\text { Reliability } \\
\text { index } \\
\text { (normal) }\end{array}$ & 19.82 & 47.76 & 67.48 & - \\
\hline & & $\begin{array}{c}\text { Reliability } \\
\text { index (log } \\
\text { normal) }\end{array}$ & 24.33 & 60.11 & 83.71 & - \\
\hline & \multirow{5}{*}{ 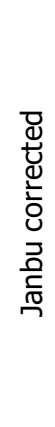 } & $\begin{array}{c}\text { Factor of } \\
\text { safety }\end{array}$ & 1.518 & 1.634 & 1.583 & 1.708 \\
\hline & & Mean FS & 1.518 & 1.633 & 1.582 & 1.708 \\
\hline & & $\begin{array}{l}\text { Prob. of } \\
\text { failure }\end{array}$ & $0 \%$ & $0 \%$ & $0 \%$ & $0 \%$ \\
\hline & & $\begin{array}{c}\text { Reliability } \\
\text { index } \\
\text { (normal) }\end{array}$ & 19.55 & 47.74 & 65.27 & - \\
\hline & & $\begin{array}{c}\text { Reliability } \\
\text { index (log } \\
\text { normal) }\end{array}$ & 23.90 & 60.39 & 81.39 & - \\
\hline & \multirow{5}{*}{ 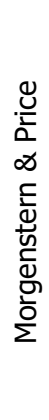 } & $\begin{array}{c}\text { Factor of } \\
\text { safety }\end{array}$ & 1.526 & 1.612 & 1.576 & 1.634 \\
\hline & & Mean FS & 1.524 & 1.612 & 1.576 & 1.633 \\
\hline & & $\begin{array}{l}\text { Prob. of } \\
\text { failure }\end{array}$ & $0 \%$ & $0 \%$ & $0 \%$ & $0 \%$ \\
\hline & & $\begin{array}{c}\text { Reliability } \\
\text { index } \\
\text { (normal) }\end{array}$ & 19.32 & 47.52 & 68.38 & - \\
\hline & & $\begin{array}{c}\text { Reliability } \\
\text { index (log } \\
\text { normal) }\end{array}$ & 23.67 & 59.77 & 85.10 & - \\
\hline
\end{tabular}

The minimum reliability index value recommended is three to guarantee a safe slope design [7]. From the results, it's observed that all reliability index values from all projects (except for project 3 with the gabion's wall alternative) are higher than three. One of the advantages of performing a probabilistic-based design is that it is possible to estimate the confidence in the estimation of the levels of safety. For example, it could be inferred that project 3 with the MSE wall alternative exhibits lower uncertainty than project 1 , even though they both have similar safety factors. Also, project 2 shows a lower reliability index value than project 3 , which means is less reliable. Additionally, there is a tendency of obtaining higher values of reliability index considering the lognormal statistical distribution.

It is worth mentioning that when a probabilistic approach is used, the resulting design is not necessarily different than the one obtained from a deterministic approach. If this is the case, one could argue that performing a probabilistic design is unnecessary, however, even if the structural dimensions are the same, the quantification of the level of safety is better assessed since the probabilistic methodology will require to reflect on the design parameter in a way that reduces its uncertainty. As it is well-known, soil's properties are highly variable, and it can be argued that a big part of this variability is associated with changes in the degree of saturation. Hence, obtaining adequate statistical parameters requires the consideration of the unsaturated soil conditions.

\section{Conclusions}

The advantages of performing probabilistic-based geotechnical design are well-known. However, sometimes enough data is not available in order to do a full statistical analysis necessary to obtain mean and standard deviation values for relevant design parameters. In these cases, it is possible to utilize values presented in the technical literature. Three different projects were presented where local statistical parameters were used for total unit weight, undrained cohesion, effective angle of friction of the soil, and degree of saturation, selected from a previous research project conducted by the author. It is worth mentioning that for a probabilistic analysis to be fully understood special attention must be given not only to the mean safety factor, but also to probability of failure and the reliability index, so the actual uncertainty can be assessed. For example, having a higher safety factor does not necessarily imply that the design is safer because is possible to have a higher reliability index with a lower safety factor and vice versa.

The statistical parameter selected from the previous research can be used as local literature values to perform probabilistic geotechnical designs and analyses when there is not enough data to execute a statistical analysis in a project. Moreover, these values could be used to better understand values obtained from geotechnical site exploration and possible regional tendencies.

It is possible to conduct probabilistic geotechnical design even when a project does not include a throughout site exploration, like in low-budget projects.

Probabilistic design for rural road projects can be a useful tool in the pursuit of optimal and efficient designs where the soil behavior is better understood.

\section{References}

1. Federal Highway Administration (FHWA) of the U.S Department of Transportation. (2016). Design and Construction of Driven Pile Foundations. GEC. No. 12. 1. 
2. S. Brizuela. (2016). Diseño de un programa computacional para el análisis probabilístico de cimentaciones superficiales y muros de retención. (Graduation Project, University of Costa Rica).

3. Costa Rica's Geotechnics Association. (2010). Foundation's Code of Costa Rica (Second edition).

4. G.R. Bogantes. (2002). Zonificación Geotécnica General de Costa Rica considerando elementos edáficos y climáticos. VIII Geotechnic's National Seminar and III Center American Encounter of Geotechnical People. 159-181.

5. E. Valverde. (2012). Diseño probabilístico de cimentaciones profundas cuantificando la incertidumbre asociada al grado de saturación en San José y Cartago. (Graduation Project, University of Costa Rica).

6. Costa Rica's Geotechnics Association. (2015). Slope's Geotechnical Code of Costa Rica.

7. Rocscience Inc. (n.d.). Probabilistic Analysis Tutorial Slide 6.0. 